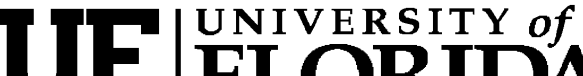 FLORIDA \\ IFAS Extension
}

\section{Florida 4-H Horticulture Identification and Judging: Contest Rules and Glossary 1}

Jeffrey G. Williamson, Sydney Park Brown, and Tom Wichman ${ }^{2}$

This publication provides guidelines and information for Florida 4H members and Master Gardeners interested in horticulture and/or in participating in state contests held annually at 4-H Congress or the Master Gardener Annual Conference.

These contests provide the opportunity to study horticultural plants and their parts and products. Participation in the contest should result in improved abilities to recognize, use, grow, and appreciate the offerings of horticulture.

Horticulture is the art and science of growing fruits and nuts, vegetables, flowers and foliage plants and ornamental plants. Horticulture is a profession, a vocation, a hobby, an industry, and a way of life for millions of people. Horticulture is very important to Florida's economy and is vital to everyone's health and well-being.

\section{Eligibility}

1. 4-H youth participants must comply with all 4-H rules and regulations governing county, district and state events. For more information and regulations regarding 4-H eligibility, see the following Web page: http://florida4h.org/events/files/20082010_Events_And_Activities_Handbook_low.pd $\mathrm{f}$

2. 4-H contestants are urged to participate first at the local and county level, but district elimination is not required in the state contests. Each county 4-H program may enter one 4-H senior team in the competition. Junior teams may participate to gain experience. Only one Master Gardener team can compete from each county, but individual Master Gardeners can participate for practice or as competitors.

3. A 4-H or Master Gardener team consists of three to four members (only the top three scores are combined for a total team score). Team members also compete independently.

1. This publication is 4H PSJ 20, part of a series of the Environmental Horticulture Department, Florida Cooperative Extension Service, Institute of Food and Agricultural Sciences, University of Florida. Original publication date, March 1992. Orginal authors included Kathleen C. Ruppert, at that time an assistant professor, Environmental Horticulture Department; Robert J. Black, then an associate professor, Environmental Horticulture Department, and James M. Stephens, professor emeritus, Horticultural Sciences Department. This publication was revised in August of 2009.

2. Jeffrey G. Williamson, professor, Horticultural Sciences Department; Sydney Park Brown, extension associate professor, Environmental Horticulture Department, Gulf Coast Research and Education Center--Plant City, FL; and Tom Wichman, extension agent II, Environmental Horticulture Department, Cooperative Extension Service, Institute of Food and Agricultural Sciences, University of Florida, Gainesville FL. 
4. Individual or team state winners are not eligible to compete in future state 4-H Horticulture ID/Judging events. However, Master Gardener state winners (teams or individuals) may compete year after year.

\section{Identification}

The identification section of the contest includes four groups of plants: fruits and nuts, vegetables, flowers and foliage plants and ornamental plants (woody plants, vines, groundcovers and ornamental grasses). Each group contains 50 plants. Participants are responsible for knowing all 200 plants although only 35 specimens from each group (140 total) will be included in the contest.

The following Web site contains descriptions and color images of all the 200 plants, as well as "self-tests" for each group:

http://gardeningsolutions.ifas.ufl.edu/mastergardener/ outreach/plant_id/ Botanical terms are linked to an on-line glossary; the glossary is also available at the end of this document.

Specimens for identification may be the plant, plant parts, or plant products. There are no duplications on the contest. Four score sheets are used for the identification section - one for each group. Each score sheet lists the plants in that group (see score sheets below). In the blank provided on the score sheet, the contestant must write the appropriate specimen number for each plant. Each item counts five points for a total possible score of 700 on the identification section.

\section{Judging}

The judging section of the contest consists of eight classes of horticultural plants or produce:

1. Two classes of fruits.

2. Two classes of vegetables.

3. Two classes of flowers and/or foliage plants.

4. Two classes of ornamental plants (woody plants vines, groundcovers and ornamental grasses).
Each class consists of four individual or grouped specimens, lettered ABCD from left to right. Mentally arrange the specimens in order of highest to lowest overall quality and mark them in the appropriate space on the judging score sheet in the column labeled "Placing."

Judging counts for 200 points (25 points for each of the eight classes). Correct selection of the best group or specimen within a class is worth 76 percent of the total score for that class regardless of how the other three groups are ranked. By correctly placing the best and worst groups (specimens) within a class, the contestant earns 88 percent of the possible points for that class; 100 percent is considered correct placing.

The final score is determined by dividing the sum total of percentages by four to obtain the total points. For example, if all eight classes are placed correctly, the scoring would be as follows:

$100 \%$ x $8=800 \div 4=200$ points scored.

See Table 5 for an example of a Judging Sheet/Score Card.

\section{Judging Fruits and Vegetables}

General guidelines are presented here to help you better recognize high-quality fruits and vegetables and rank each class accordingly.

Judging fruits and vegetables is simply a matter of making choices. Consumers buy fruits and vegetables at the market by selecting those most appealing to them on the basis of external quality and past experience. Visit produce markets or produce sections of grocery stores to examine fruits and vegetables. Try to identify the best-quality produce and determine why some produce is of inferior quality.

Notice the behavior of other shoppers. Almost everyone "selects" fruits and vegetables. They don't just take the first ones or closest ones. The key to success in this contest is learning, through experience, how to select the best produce. 
Judging fruits and vegetables is based on common-sense factors. The following criteria should be used when evaluating the quality of produce:

1. Specimens should be fresh and at the optimum stage of maturity for eating. Produce that is over-mature or immature is downgraded.

2. Specimens should be clean and free from insects and diseases or any damage caused by such pests.

3. Specimens should be free of bruises and blemishes. Although many surface blemishes do not affect eating quality, they do reduce eye appeal.

4. Grouped specimens should be uniform in size, shape, color and type. Each group within a class will have the same number of specimens.

When grading, first visualize the ideal specimen. Then consider all departures from this based on the above criteria and common sense. Factors that affect usefulness are downgraded more than other factors. For example, severely overripe bananas would be ranked below bananas with slight abnormalities in size or shape. The specimen(s) with the most defects and serious faults should receive the lowest rankings. It is usually best to first identify the worst group within a class, then pick the best of the remaining three groups. Finally, try to place the final two groups in rank order.

\section{Judging Flowers and Foliage}

Flowers are divided into two categories for judging purposes: cut flowers and potted plants.

Cut flowers can be divided into two main forms: spike and round. Gladiolus and snapdragon are examples of spike flowers, and the rose and chrysanthemum are examples of round flowers.

When judging spike flowers, look for long spikes with the greatest number of open flowers. The bottom flowers should show no signs of over-maturity (i.e., browning around the edges, shriveling or fading of color). Spike-form flowers should be just single spikes with no secondary side shoots.
Maturity is an important factor when judging round-form flowers. The center petals should not be so tight and immature as to be green, but they should be tighter than the outer petals. The outer petals should begin to turn down, but show no signs of wilting and drying.

Flowers should be of one variety or cultivar and have typical characteristics of that variety. Flowers should be free of irregularities, spray residue and blemishes due to insect, disease or mechanical injury. Stems should all be the same length, straight and strong enough to support the flower head without bending. Foliage should be clean, fresh and a bright shade of green.

Bloom size, color, freshness, arrangement of petals and symmetry are other important points to consider when judging cut flowers.

Potted flowering plants should be short, compact, well shaped and have dark-green foliage with flower buds just beginning to show color or perhaps with a few buds open. Specimens having the most flower buds are normally more desirable.

Judging foliage plants is similar to judging potted plants, but much more attention should be given to the quality of the foliage. Criteria to consider include the size, color and number of the leaves, as well as the size and shape of the plant, and whether it appears to be growing and healthy.

\section{Glossary of Botanical Terms}

Alternate Leaf Arrangement: One leaf at a node. (See Figure 1.)

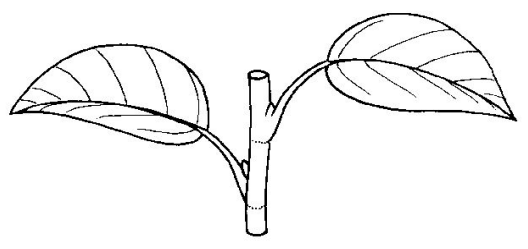

Figure 1.

Annual: A plant that completes its life cycle in one season. In Florida annuals are typically referred to as warm-season or cool-season.

Apical: At the tip, as in the end of a shoot or root. 
Basal: Leaves that grow at the base of the stem.

Berry Type Fruit: A simple, pulpy fruit, such as blueberry, grape or tomato. (See Figure 2.)

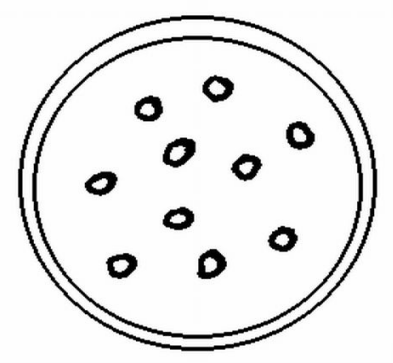

Figure 2.

Biennial: A plant that completes its life cycle in two growing seasons.

Bipinnate: Twice pinnate, with leaflets arranged on each side of a common stalk. (See Figure 3.)

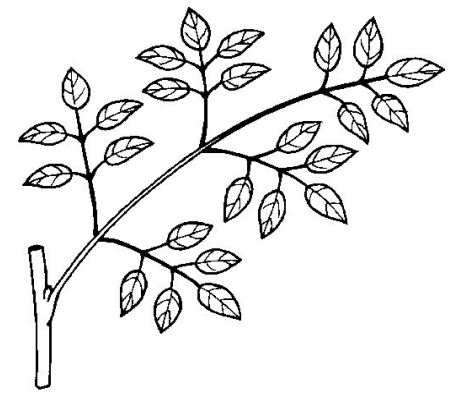

Figure 3.

Bloom: A waxy, white covering on leaves or fruit; a name for the flowering part of a plant.

Bract: A more-or-less-modified leaf, situated near a flower. Ex: The brightly colored "petals" of a poinsettia are actually bracts.

Branchlets: Small branches growing from a larger branch.

Bud: Much-condensed, undeveloped shoot.

Bulb: A short, modified stem, the thickened leaves of which store reserved food. Amaryllis, onion and garlic are examples of plants that grow from bulbs.

Bulbous: Like a bulb or producing a bulb.

Catkins: A dense spike or raceme without petals, having only male or female reproductive parts.
Columnar: Slender, upright form.

Compound Leaf: A leaf composed of two or more leaflets.

Coniferous: Cone-bearing.

Cordate Leaf Shape: Heart-shaped. (See Figure 4.)

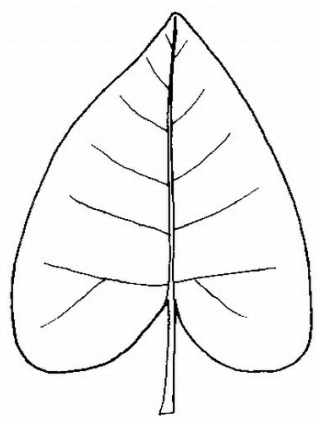

Figure 4.

Corm: A thickened, vertical, solid, underground stem. Gladiolus and caladium are examples of plants that grow from corms.

Cormels: Small corms that arise from a larger corm.

Corolla: Collective name for petals.

Corymb Flower Arrangement: An inflorescence consisting of a central rachis bearing a number of branched pedicels - the lower ones much longer than the upper - resulting in a flat or more or less round-topped cluster. (See Figure 5.)

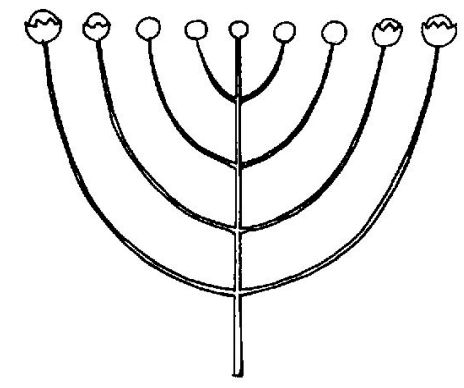

Figure 5.

Crenate Leaf Margin: Blunt, rounded teeth. (See Figure 6.)

Cyme Flower Arrangement: An inflorescence consisting of a central rachis bearing a number of pedicelled flowers. (See Figure 7.) 


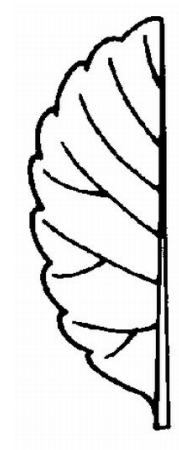

Figure 6.

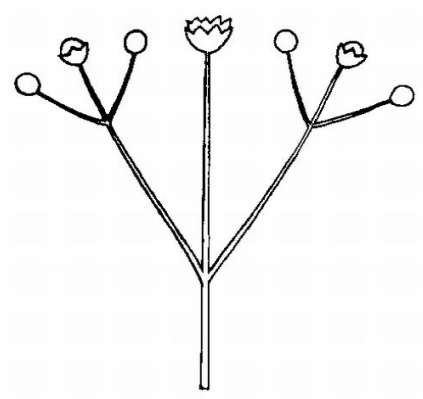

Figure 7.

Deciduous: A plant that sheds its leaves during certain seasons of the year.

Dioecious: Male and female flowers are borne on different plants. Ex: hollies, wax myrtle.

Drupe Fruit Type: A fruit with four major parts -- a thin skin, a fleshy body, a hard stone and an inner seed. Ex: Peach. (See Figure 8.)

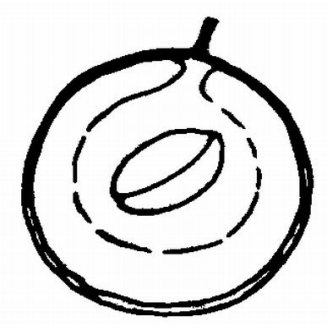

Figure 8.

Elliptic Leaf Shape: Broadest at the middle with the ends nearly equal. (See Figure 9.)

Entire Leaf Margin: Uncut, without indentations. (See Figure 10.)

Evergreen: Bearing leaves throughout the year.

Exfoliating: Peeling off in thin layers.

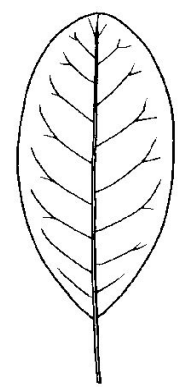

Figure 9.

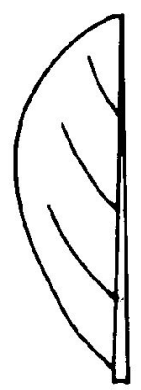

Figure 10.

Floret: A small flower or an individual flower in a cluster.

Funnelform Corolla Type: Tube gradually expanding upward as a funnel. The limb may be flaring or somewhat at right angles to the flower axis. (See Figure 11.)

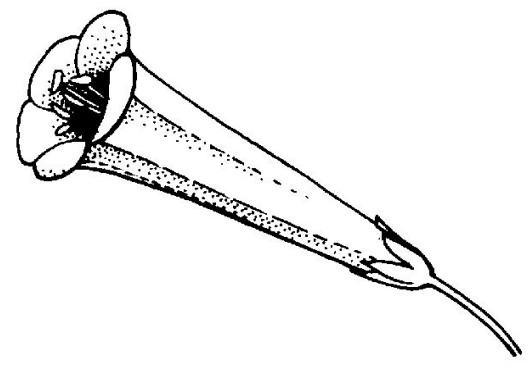

Figure 11.

Glabrous: Smooth, no hairs present.

Globose or Globular: Rounded or like a sphere.

Gymnosperm: Cone-bearing plants, considered to be more primitive than flowering plants. Ex: Pine trees.

Herbaceous: A plant with no persistent woody stem above ground.

Husk: The hard or tough layer that covers some fruits and seeds. 
Indehiscent: A fruit that does not open spontaneously to release seeds.

Inflorescence: The flowering part of a plant.

Internode: The part of the stem that is between two nodes.

Kernel: The inner and usually edible part of a seed, grain or nut.

Lanceolate: Shaped as the head of a lance, broadened at the base and tapering toward the apex. (See Figure 12.)

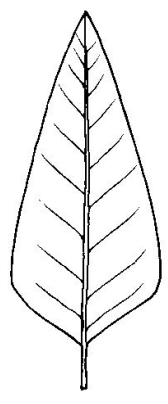

Figure 12.

Leaf Axil: The angle between the stem and the upper surface of an attached leaf.

Leaflet: One of the divisions of a compound leaf.

Lenticels: A group of raised, corky cells that form beneath the epidermis of a woody plant.

Linear: Long and narrow, the sides parallel or nearly so. (See Figure 13.)

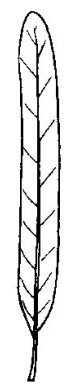

Figure 13.

Lobed Leaf Margin: Divided into lobes separated by narrow or acute indentations, which extend from one-third to one-half of the distance between margin and midrib. (See Figure 14.)

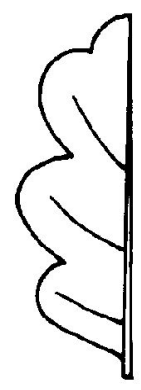

Figure 14.

Margin: The outer edge of a leaf.

Midrib: The main or central vein of a leaf.

Monoecious: Male and female flowers are borne on the same plant.

Node: The place on the stem that normally bears a leaf.

Oblanceolate Leaf Shape: The broadest half above the middle and tapering toward the apex; the reverse of lanceolate. (See Figure 15.)

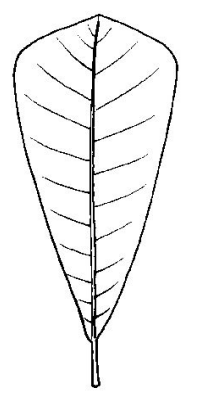

Figure 15.

Oblate: Spherical, flattened on both ends.

Oblong: Longer than broad and with sides nearly parallel. (See Figure 16.)

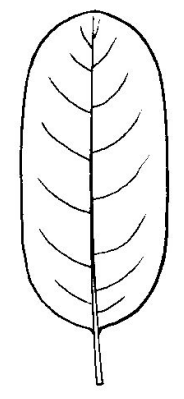

Figure 16.

Obovate: Inversely ovate, with the broadest half above the middle. (See Figure 17.) 


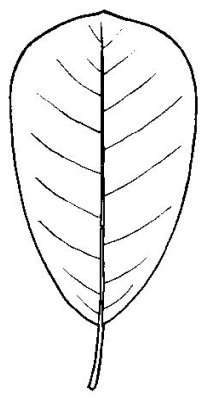

Figure 17.

Odd-pinnately Compound: A compound leaf terminated by a leaflet. (See Figure 18.)

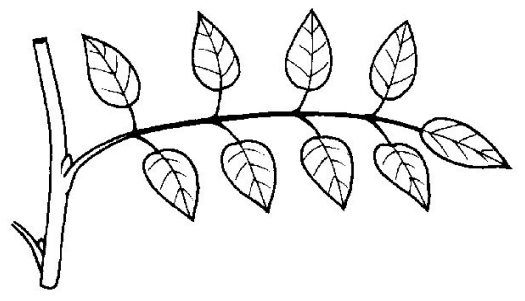

Figure 18.

Opposite Leaf Arrangement: Two leaves at a node, one on the opposite side of the stem from the other. (See Figure 19.)

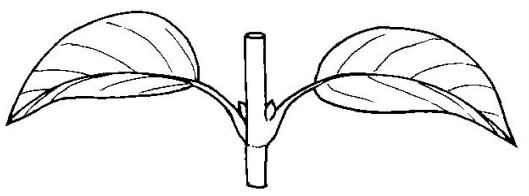

Figure 19.

Oval Leaf Shape: Broadly elliptical, with the width usually greater than one half of the length. (See

Figure 20.)

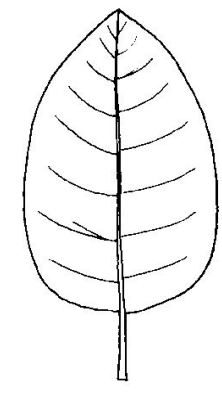

Figure 20.

Ovary: Basal portion of the female flower that becomes a fruit.

Ovate Leaf Shape: Egg-shaped, with the broadest half below the middle. (See Figure 21.)

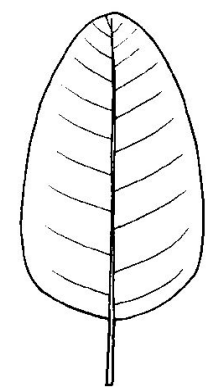

Figure 21.

Ovoid: Shaped like an egg with the stem attachment at the broad end.

Palmate: A pattern where the leaves or leaf veins radiate from one point (as fingers radiate from the palm of a hand).

Panicle: A branched inflorescence where the bottom flowers open first.

Pedicel: The stalk of a single flower in an inflorescence.

Perennial: A plant that grows indefinitely.

Petal: One of the individual parts of the corolla.

Petiole: Stalk supporting the leaf.

Pinnate: A pattern where the leaves or leaf veins are arranged like a feather. In venation, major veins extend from the midrib to the margin (See Figure 20).

Pinnately compound: A compound leaf divided into leaflets arranged on opposite sides of the stem.

Pit: The stone of a fruit, such as in a plum or cherry.

Pith: Soft, spongy tissue in the center of the stem or roots.

Pods: Dry fruit that opens when mature.

Pome Fruit Type: A fleshy fruit having seed chambers and an outer fleshy part. Ex: apple and pear. (See Figure 22.)

Prickles: A small, spine-like growth.

Pubescent: Covered with short, soft hairs.

Pyramidal: Shaped like a pyramid, with a broad base and tapered point. 


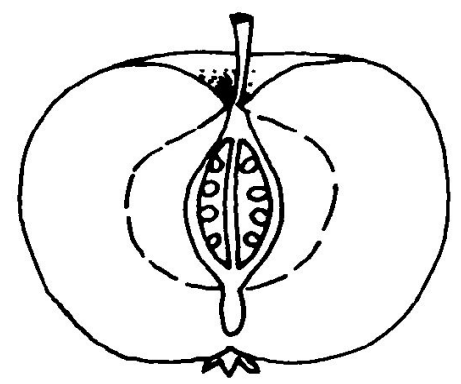

Figure 22.

Raceme Flower Arrangement: An inflorescence consisting of a central stem bearing a number of pedicelled flowers with the pedicels of nearly equal length. (See Figure 23.)

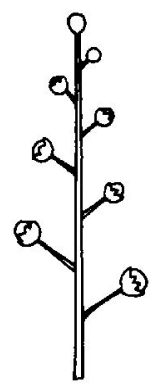

Figure 23.

Receptacle: The enlarged upper end of the stalk of a flowering plant, on which the flower parts are held.

Revolute Leaf Margin: Rolled backward, or underneath. (See Figure 24.)

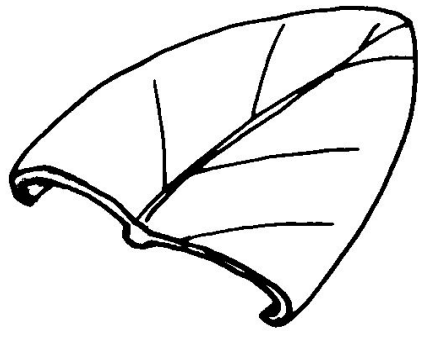

Figure 24.

Rhizome: Any prostrate, elongated, stem, growing partially or completely beneath the surface of the ground.

Rosette Leaf Arrangement: Arrangement of leaves radiating from a crown or center and usually growing close to the ground. (See Figure 25.)

Samara Fruit Type: Winged fruit; dry, indehiscent. (See Figure 26.)

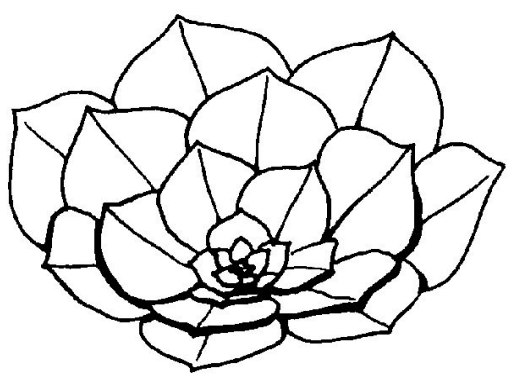

Figure 25.

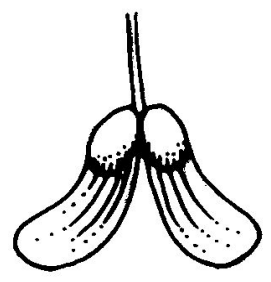

Figure 26.

Scale-like Leaf Shape: Small, short, usually sharp-pointed, broadened at the base. (See Figure 27.)

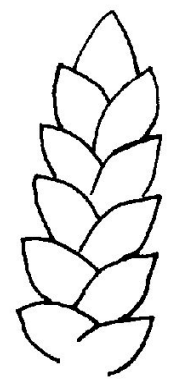

Figure 27.

Segments: In palms, leaf is deeply lobed, but not divided.

Sepal: Usually green in color and one of the parts of the outer whorl of a flower.

Serrate Leaf Margin: Sharp teeth pointing toward the apex. (See Figure 28.)

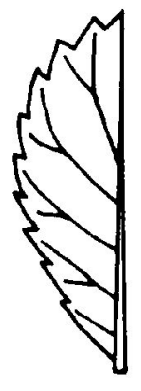

Figure 28. 
Simple Leaf: An undivided leaf; without leaflets. (See Figure 29.)

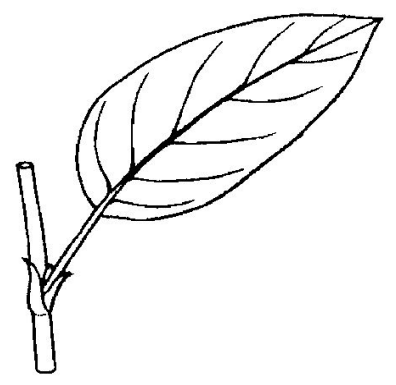

Figure 29.

Solitary: Single, one flower.

Spadix: A flower spike, usually densely flowered with imperfect flowers, and having a thick and fleshy axis. (See Figure 30.)

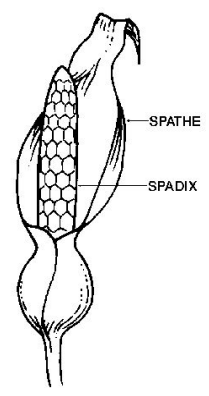

Figure 30.

Spathe: A large bract sheathing or enclosing a spadix. (See Figure 30.)

Spike Flower Arrangement: An inflorescence consisting of a central rachis bearing a number of flowers directly attached to the flower stem (i.e., no pedicels). (See Figure 31.)

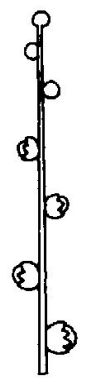

Figure 31.

Spore: A small, reproductive structure capable of developing into a new organism. Ferns and fungi are examples of organisms that use spores to reproduce.
Spur: In fruit, a short shoot that bears the fruit; in flowers, a tubular projection of the corolla.

Stamen: The male, pollen-bearing organ of a flower, an organ consisting of a filament and anther. (See Figure 32.)

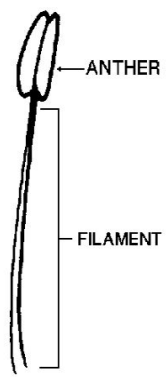

Figure 32.

Stolon: Trailing stem above ground, rooting at the nodes.

Stone: The woody portion of the protective enclosure surrounding a seed.

Stone cell: Hard cells with thick walls that provide support to the plant and give the flesh a gritty texture.

Subopposite: Nearly alternate, but with close spacing.

Succulent: Fleshy and full of juice.

Suture: In fruit, the line where the dry fruit splits open.

Tendril: A modified leaf or stem, slender and coiling, used for grasping or attaching to a support.

Trifoliate: A compound leaf having three leaflets.

Tuber: A thickened, short, usually subterranean stem having numerous buds, called eyes. Ex: potato.

Tunicate: Having enwrapping coats or layers, like an onion.

Umbel Flower Arrangement: An inflorescence consisting of several pedicelled flowers with a common point of attachment. (See Figure 33.)

Undulate Leaf Margin: Wavy leaf edge (up and down in a vertical plane). (See Figure 34.) 


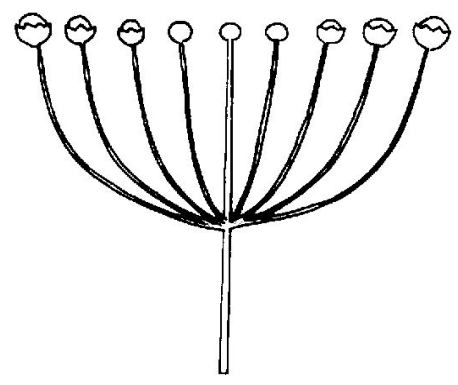

Figure 33.

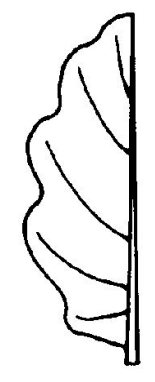

Figure 34 .

Whorled Leaf Arrangement: Three or more leaves at a node. (See Figure 35.)

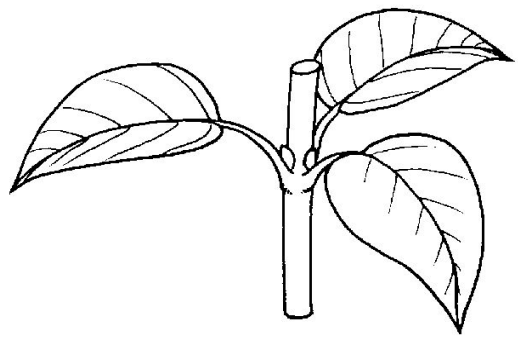

Figure 35. 
Table 1. Fruits and Nuts

\begin{tabular}{|c|c|c|}
\hline Specimen \# & Common Name & Botanical Name \\
\hline & Apple & Malus domestica \\
\hline & Apricot & Prunus armeniaca \\
\hline & Avocado & Persea americana \\
\hline & Banana & Musa spp. \\
\hline & Barbados Cherry & Malpighia glabra \\
\hline & Black Walnut & Juglans nigra \\
\hline & Blackberry & Rubus spp. \\
\hline & Blueberry & Vaccinium spp. \\
\hline & Carambola & Averrhoa carambola \\
\hline & Cashew & Anacardium occidentale \\
\hline & Cherry & Prunus avium \& Prunus cerasus \\
\hline & Chestnut & Castanea mollissima \\
\hline & Chinese Jujube & Zizyphus jujuba \\
\hline & Coconut & Cocos nucifera \\
\hline & Elderberry & Sambucus canadensis \& Sambucus simpsonii \\
\hline & Fig & Ficus carica \\
\hline & Grape, Bunch & Vitis vinifera \\
\hline & Grape, Muscadine & Vitis rotundifolia \\
\hline & Grapefruit & Citrus paradisi \\
\hline & Guava & Psidium guajava \\
\hline & Hickory Nut & Carya spp. \\
\hline & Kiwi Fruit & Actinidia deliciosa \\
\hline & Kumquat & Fortunella spp. \\
\hline & Lemon & Citrus limon \\
\hline & Lime & Citrus aurantifolia \& Citrus latifolia \\
\hline & Loquat & Eriobotrya japonica \\
\hline & Lychee & Litchi chinensis \\
\hline & Mamey Sapote & Pouteria sapota \\
\hline & Mango & Mangifera indica \\
\hline & Mayhaw & Crataegus spp. \\
\hline & Mulberry & Morus spp. \\
\hline & Persimmon, Japanese & Diospyros kaki \\
\hline & Persimmon, Native & Diospyros virginiana \\
\hline & Nectarine & Prunus persica var. nucipersica \\
\hline & Orange & Citrus sinensis \\
\hline & Papaya & Carica papaya \\
\hline & Passion Fruit & Passiflora edulis \\
\hline & Paw Paw & Asimina triloba \\
\hline & Peach & Prunus persica \\
\hline & Pear & Pyrus communis \\
\hline & Pecan & Carya illinoinensis \\
\hline & Pineapple & Ananas comosus \\
\hline & Plum & Prunus spp. \\
\hline & Pomegranate & Punica granatum \\
\hline & Quince & Cydonia oblonga \\
\hline & Raspberry & Rubus spp. \\
\hline
\end{tabular}


Table 1. Fruits and Nuts

\begin{tabular}{||l|l|l||}
\hline \hline Specimen \# & Common Name & Botanical Name \\
\hline & Strawberry & Fragaria spp. \\
\hline & Sugar Apple & Annona squamosa \\
\hline & Tangelo & Citrus reticulata x Citrus paradisi \\
\hline & Tangerine & Citrus reticulata \\
\hline
\end{tabular}

Table 2. Vegetables

\begin{tabular}{|c|c|c|}
\hline Specimen \# & Common Name & Botanical Name \\
\hline & Artichoke, Globe & Cynara scolymus \\
\hline & Artichoke, Jerusalem & Helianthus tuberosus \\
\hline & Asparagus & Asparagus officinalis \\
\hline & Bean, Lima & Phaseolus lunatus \\
\hline & Bean, Snap & Phaseolus vulgaris \\
\hline & Beet & Beta vulgaris \\
\hline & Broccoli & Brassica oleracea (Italica) \\
\hline & Brussels Sprouts & Brassica oleracea (Gemmifera) \\
\hline & Cabbage & Brassica oleracea (Capitata) \\
\hline & Cantaloupe & Cucumis melo (Reticulatus) \\
\hline & Carrot & Daucus carota var. sativus \\
\hline & Cauliflower & Brassica oleracea (Botrytis) \\
\hline & Celery & Apium graveolens var. dulce \\
\hline & Chayote & Sechium edule \\
\hline & Chinese Cabbage & Brassica campestris (Chinensis and Pekinensis) \\
\hline & Chives & Allium schoenoprasum \\
\hline & Collards & Brassica oleracea (Acephala) \\
\hline & Cucumber & Cucumis sativus \\
\hline & Eggplant & Solanum melongena var. esculentum \\
\hline & Endive & Cichorium endivia \\
\hline & Escarole & Cichorium endivia \\
\hline & Fennel & Foeniculum vulgare \\
\hline & Garbanzo & Cicer arietinum \\
\hline & Garlic & Allium sativum \\
\hline & Kale & Brassica oleracea (Acephala) \\
\hline & Kohlrabi & Brassica oleracea (Gongylodes) \\
\hline & Leek & Allium ampeloprasum (Porrum) \\
\hline & Lettuce & Lactuca sativa \\
\hline & Malanga & Xanthosoma spp. \\
\hline & Mustard & Brassica juncea var. crispifolia \\
\hline & Okra & Hibiscus esculentus \\
\hline & Onion & Allium cepa \\
\hline & Parsley & Petroselinum crispum \\
\hline & Parsnip & Pastinaca sativa \\
\hline & Pea, English & Pisum sativum \\
\hline & Pea, Southern & Vigna unguiculata \\
\hline & Pepper & Capsicum annuum \\
\hline
\end{tabular}


Table 2. Vegetables

\begin{tabular}{||l|l|l||}
\hline \hline Specimen \# & \multicolumn{1}{|c|}{ Common Name } & \multicolumn{1}{c|}{ Botanical Name } \\
\hline & Potato, Irish & Solanum tuberosum \\
\hline & Potato, Sweet & Ipomoea batatas \\
\hline & Rutabaga & Brassica napus (Napobrassica) \\
\hline & Sage & Salvia officinalis \\
\hline & Spinach & Spinacia oleracea \\
\hline & Squash, Butternut & Cucurbita moschata \\
\hline & Squash, Zucchini & Cucurbita pepo \\
\hline & Summer Radish & Raphanus sativus \\
\hline & Sweet Corn & Zea mays var. saccharata \\
\hline & Swiss Chard & Beta vulgaris (Cicla) \\
\hline & Tomato & Lycopersicon esculentum \\
\hline & Turnip & Brassica campestris (Ruvo) \\
\hline & Watermelon & Citrullus lunatus \\
\hline
\end{tabular}

Table 3. Flowers and Foliage Plants

\begin{tabular}{|c|c|c|}
\hline Specimen \# & Common Name & Botanical Name \\
\hline & African Violet & Saintpaulia spp. \\
\hline & Aglaonema & Aglaonema commutatum \\
\hline & Aloe Vera & Aloe barbadensis \\
\hline & Amaryllis & Hippeastrum spp. \\
\hline & Anthurium & Anthurium spp. \\
\hline & Begonia & Begonia spp. \\
\hline & Blanket Flower & Gaillardia spp. \\
\hline & Caladium & Caladium x spp. \\
\hline & Calathea & Calathea spp. \\
\hline & Canna & Canna $\mathrm{x}$ generalis \\
\hline & Celosia & Celosia spp. \\
\hline & Chrysanthemum & Dendranthema x grandiflorum \\
\hline & Coleus & Solenostemon scutellarioides \\
\hline & Coreopsis, Tickseed & Coreopsis spp. \\
\hline & Daylily & Hemerocallis spp. \\
\hline & Dendrobium Orchids & Dendrobium spp. \\
\hline & Dianthus & Dianthus chinensis \\
\hline & Dieffenbachia & Dieffenbachia spp. \\
\hline & Dracaena Marginata & Dracaena marginata \\
\hline & English Ivy & Hedera helix \\
\hline & False Heather, Mexican Heather & Cuphea hyssopifolia \\
\hline & Geranium & Pelargonium $\mathrm{x}$ hortorum \\
\hline & Gerbera Daisy & Gerbera jamesonii \\
\hline & Gladiolus & Gladiolus x hortulanus \\
\hline & Globe Amaranth & Gomphrena globosa \\
\hline & Gloxinia & Sinningia speciosa \\
\hline & Heart-Leaf Philodendron & Philodendron scandens subsp. oxycarium \\
\hline & Holly Fern & Cyrtomium falcatum \\
\hline
\end{tabular}


Table 3. Flowers and Foliage Plants

\begin{tabular}{|c|c|c|}
\hline Specimen \# & Common Name & Botanical Name \\
\hline & Impatiens & Impatiens spp. \\
\hline & Jade Plant & Crassula argentea \\
\hline & Lily of the Nile & Agapanthus praecox \& Agapanthus ssp. orientalis \\
\hline & Marigold & Tagetes spp. \\
\hline & Moth Orchid & Phalaenopsis spp. \\
\hline & Neanthe Bella Palm & Chamaedorea elegans \\
\hline & Nephthytis & Syngonium podophyllum \\
\hline & Pentas & Pentas lanceolata \\
\hline & Peperomia & Peperomia spp. \\
\hline & Periwinkle & Catharanthus roseus \\
\hline & Poinsettia & Euphorbia pulcherrima \\
\hline & Pothos & Epipremnum pinnatum Aureum \\
\hline & Salvia & Salvia spp. \\
\hline & Sansevieria & Sansevieria spp. \\
\hline & Spathiphyllum & Spathiphyllum spp. \\
\hline & Spider Plant & Chlorophytum comosum \\
\hline & Stokes Aster & Stokesia laevis \\
\hline & Torenia, Wishbone Flower & Torenia fournieri \\
\hline & Verbena & Verbenia x hybrida \\
\hline & Weeping Fig & Ficus benjamina \\
\hline & Zebra Plant & Aphelandra squarrosa \\
\hline & Zinnia & Zinnia elegans \\
\hline
\end{tabular}

Table 4. Ornamentals (Woody Plants, Vines, Groundcovers and Ornamental Grasses)

\begin{tabular}{|c|c|c|}
\hline Specimen \# & Common Name & Botanical Name \\
\hline & Allamanda & Allamanda cathartica \\
\hline & American Holly & Ilex opaca \\
\hline & Anise & Illicium parviflorum \\
\hline & Azalea & Rhododendron spp. \\
\hline & Bald Cypress & Taxodium distichum \\
\hline & Beautyberry & Callicarpa americana \\
\hline & Black Olive & Bucida buceras \\
\hline & Bougainvillea & Bougainvilllea spp. \\
\hline & Burford Holly & Ilex cornuta Burfordii \\
\hline & Cabbage Palm & Sabal palmetto \\
\hline & Camellia & Camellia spp. \\
\hline & Carissa (Natal Plum) & Carissa grandiflora \\
\hline & Cherokee Bean & Erythrina herbacea \\
\hline & Chinese Elm & Ulmus parvifolia \\
\hline & Chinese Fringe Bush & Loropetalum chinense \\
\hline & Coontie & Zamia floridana \\
\hline & Coral Honeysuckle & Lonicera sempervirens \\
\hline & Crepemyrtle & Lagerstroemia indica \\
\hline & Croton & Codiaeum variegatum \\
\hline
\end{tabular}


Florida 4-H Horticulture Identification and Judging: Contest Rules and Glossary

Table 4. Ornamentals (Woody Plants, Vines, Groundcovers and Ornamental Grasses)

\begin{tabular}{||l|l|l||}
\hline \hline Specimen \# & \multicolumn{1}{|c|}{ Common Name } & \multicolumn{1}{|c||}{ Botanical Name } \\
\hline & Dogwood & Cornus florida \\
\hline & Fakahatchee Grass, Gama Grass & Tripsacum floridanum \\
\hline & Feijoa & Acca sellowiana \\
\hline & Glossy Abelia & Abelia x grandiflora \\
\hline & Hibiscus & Hibiscus rosa - sinensis \\
\hline & Indian Hawthorn & Rhaphiolepis indica \\
\hline & Ixora & Ixora coccinea \\
\hline & Japanese Privet & Ligustrum japonicum \\
\hline & Liriope & Liriope muscari \\
\hline & Live Oak & Quercus virginiana \\
\hline & Loblolly Bay & Gordonia lasianthus \\
\hline & Mondo Grass & Ophiopogon japonicus \\
\hline & Muhly Grass & Muhlenbergia capillaris \\
\hline & Pfitzer Juniper & Juniperus chinensis var. chinensis Pfitzerana \\
\hline & Pindo Palm & Butia capitata \\
\hline & Pine & Pinus spp. \\
\hline & Pittosporum & Pittosporum tobira \\
\hline & Podocarpus & Podocarpus macrophyllus \\
\hline & Red Maple & Acer rubrum \\
\hline & Redbud & Cercis canadensis \\
\hline & River Birch & Betula nigra \\
\hline & Royal Poinciana & Delonix regia \\
\hline & Sago Palm & Cycas revoluta \\
\hline & Sea Grape & Coccoloba uvifera \\
\hline & Shore Juniper & Juniperus conferta \\
\hline & Shumard Oak & Quercus shumardii \\
\hline & Southern Magnolia & Magnolia grandiflora \\
\hline & Sweet Gum & Liquidambar styraciflua \\
\hline & Sycamore & Platanus occidentalis \\
\hline & Wax Myrtle & Myrica cerifera \\
\hline & Yaupon Holly & Ilex vomitoria \\
\hline & \\
\hline & \\
\hline & & \\
\hline & & \\
\hline & & \\
\hline & & \\
\hline & & \\
\hline & & \\
\hline & & \\
\hline & & \\
\hline & & \\
\hline & & \\
\hline & & \\
\hline & &
\end{tabular}


Table 5. Judging Sheet

\begin{tabular}{l}
\hline \hline JUDGING: Eight classes of horticultural plants or produce will be judged as follows: \\
A. Two classes of flowers and foliage plants. \\
B. Two classes of fruits and nuts. \\
C. Two classes of ornamentals. \\
D. Two classes of vegetables. \\
DIRECTIONS: There are 8 classes with 4 specimens in each class. The specimens are lettered A through D from left to \\
right. When you have decided on the placing of a particular class, mark that placing opposite the appropriate class under \\
the heading "Placing". Examples might be: CBDA, ADCB, BACD, etc. Be sure to judge all 8 classes. \\
\hline CLASS
\end{tabular}

